The Gulf region is one of economic dynamism, cosmopolitanism, and lofty ambitions. With their selfconfidence and heady optimism, they may well succeed in building up a solid base of American-model, largely private universities that will offer the type and quality of training that the millions of students in the region will find seductive. As an alternative to spending years in the United States, it is very possiblethat in coming years thousands of students from India, Pakistan, Iran, Turkey, Egypt, and Palestine will seek their American degrees in Qatar, Kuwait, or the UAE in universities devoid of American students. In a region in which the United States is both admired and detested, these institutions could end up playing a cultural and political role they haven't yet considered.

\section{High Fee Market for Australian Universities?}

\section{Simon Marginson}

Simon Marginson is director of the Monash Centre for Research in International Education at Monash University, and an Australian Research Council professorial fellow. Address: Faculty of Education, Monash University, Victoria 3800, Australia. E-mail: simon.marginson@education.monash.edu.au.

$\mathrm{T}^{\mathrm{s}}$ he Australian government has announced a major reform of fee structures and loan arrangements in higher education, to be introduced from 2005. The plan modifies Australia's income-contingent, government-administered Higher Education ContributionScheme(HECS); extends government-backed student loans to the private sector; and creates the first large-scale, full-fee market in undergraduate education. It would generate a significant cost shift from government to students and their families. However, the new policies have yet to pass the Senate, the Australian upper house.

\section{Before the Reforms}

Two decades ago government was almost the sole funding source, and tuition was free. By 2001, following the HECS and fee-based markets in international and postgraduate education beginning in the late 1980s and the entrepreneurial transformation of the 1990s, governments covered only 47 percent of costs and student fees and charges, 37 percent.

In total, 35 percent of the costs of Australian universities were met by national government grants for teaching domestic students; 17 percent were financed by students through the HECS; other government income, mostly for research, made up 10 percent; and other private income, 28 percent. Finally, 11.4 percent was collected from international students.
The HECS functions in effect as a low-interest loan for tuition. Managed by government, not the universities, and set at standard rates varying by discipline-it covers a varying proportion of actual costs, with the balance paid by government-the HECS is repaid through income tax once the ex-students' annual income reaches threshold level. The HECS debt accumulates and is adjusted annually via the inflation rate, with no other interest charge. One-fifth of students pay the HECS at a discounted rate. Monies equivalent to student HECS obligations are passed from government to universities as income. The HECS is a relatively painless form of tuition charge: studies have suggested that for full-time students, deterrent effects are almost neutral as to student socioeconomic status, though the level of the HECS has been raised since these studies were carried out.

\section{New Policies}

Under the Liberal-National party government's proposals, outlined by education minister Brendan Nelson, HECS-funded higher education has been fixed at a maximum "learning entitlement" of five years. Universities will vary the HECS as they see fit, up to 30 percent above present standard levels and as low as zero to boost enrollments. The University of Sydney has already announced that it will fix all HECS charges at the maximum rate and many others are expected to follow. To "sweeten" the increase in HECSs the government has promised to raise the income threshold triggering HECS repayments by 23 percent.

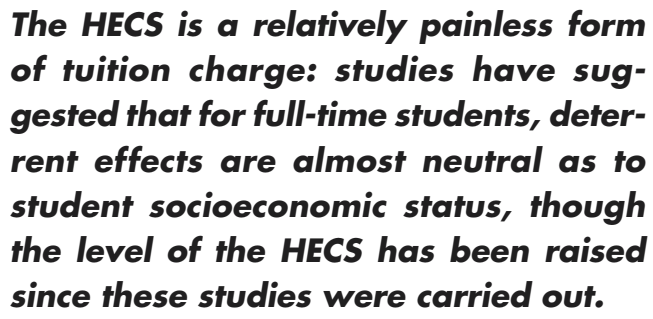

In addition to HECS undergraduate (bachelor-level) places, universities will also be able to offer full-fee places to undergraduates for 50 percent of all places in each course. Many of these places are likely to be filled as the government will introduce a Higher Education Loan Program (HELP) to cover student fees. HELP loans will be subject to interest based on inflation plus 3.5 percent and will be extended also to approved private-sector institutions. The new policies would establish a viable fee-based market in both the prestigious public universities, especially programs with high private 
returns such as law and medicine, and the private sector. Public universities now enroll 98 percent of all higher education students, but under this scenario the private sector will grow significantly.

Part of the promised increase in public funds is conditional on changes to governance structures, the introduction of performance management, and the replacement of collective bargaining with individual contracts.

The higher-status "sandstone" universities of Sydney, Melbourne, Queensland, Adelaide, and Western Australia and the newer postwar foundations of New South Wales and Monash are expected to be the chief beneficiaries. They would charge the top HECS rate and offer many full-fee places, ploughing increased private revenues into research programs, while becoming less dependent on high-volume sales of international education. Other institutions would generate less private revenues; and the promised increases in public funding, via regional loadings, the conversion of marginally funded places to full funding, increments for good teaching performance (agreed indicators are yet to be devised), and higher grants per student would be insufficient to compensate for a shortfall in revenue.

Part of the promised increase in public funds is conditional on changes to governance structures, the introduction of performance management, and the replacement of collective bargaining with individual contracts. Some vice-chancellors are pessimistic about their ability to secure these changes. Other changes in the policy package include scholarships for low socioeconomic-status-background students, albeit at only U.S.\$1,500 per year; extra places in teaching and nursing, where there are shortages; initiatives to better university teaching; funds for promoting international education in new markets, and subsidizing off-shore enrollment by domestic students, financed by increased visa charges (strongly opposed by the universities); and the extension of audits by the Australian University Quality Agency to off-shore operations that have been the subject of recent controversies.

However, the main changes are the variable and increased HECS, full-fee places, and the HELP scheme and its extension to the private sector. This is a bold neoliberal reform that shifts the ground from under the subsidized HECS as a near universal and equitable basis for financing domestic students, substituting a high-cost status market, with direct buyer-to-seller relations, at the center of the system. The university sector would be remodeled to resemble secondary schools, where almost 40 percent of students are in private institutions, led by a high-fee independent sector modeled on British schools.

The proposed policies have the support of the Australian Vice-Chancellors' Committee. However, student and faculty groups are opposed; the package conflicts with a long equity tradition in universities and is publicly unpopular; and the policies have yet to be passed by the upper house in the Australian Parliament (the Senate), where there is an antigovernment majority. The federal opposition, the Labour Party, opposes fullfee places and the proposed increases in HECS, and would introduce a modest increase in public funding instead. Some kind of package will eventually pass the Senate, as Australian universities are in financial difficulties, but whether the main features will survive Senate negotiation is unclear.

\section{Japan's National Universities Gird Themselves for the Latest Wave of Reform \\ Martin Finkelstein}

Martin Finkelstein is professor of Education at Seton Hall University and was visiting professor, in 2002-2003, at the Research Institute for Higher Education, Hiroshima University, Japan. Address: Department of Education Leadership, Management and Policy, 418 Kozlowski Hall, Seton Hall University, South Orange, NJ 07079. E-mail: finkelma@shu.edu.

$\mathrm{T}$ he foundation of Japan's national universities is about to be shaken-perhaps a lot, perhaps only a little, depending on whom you ask-by a "new" reform initiative of a scope perhaps not seen since the Allied occupation post-World War II. Betting that the "key" to the future economic resurgence of Japan lies in the creation of a world-class infrastructure for research and development at its national universities, the Ministry of Education has undertaken two major concurrent initiatives designed to introduce competitive market mechanisms into the system: (1) the authorization for the national universities to incorporate as public corporations with a Board of Trustees, independent (at least theoretically) of the ministry; and (2) the authorization and incentive for academic units across the public system to move away from the tenure system toward fixed-term contracts as the basis for faculty appointments. Both these reforms are widely viewed (although not explicitly advertised as such) as a new phase in the "Americanization" of the Japanese system. 